Journal of Applied Pharmaceutical Science Vol. 4 (10), pp. 058-061, October, 2014

Available online at http://www.japsonline.com

DOI: $10.7324 / \mathrm{JAPS} .2014 .401011$

ISSN 2231-3354 (cc) BY-NC-SA

\title{
The effects of Balanite aegyptiaca kernel cake as supplement on alloxan -induced diabetes mellitus in rats
}

\author{
M. S. Nadro*, F. P. Samson \\ ${ }^{1}$ Department of Biochemistry, Modibbo Adama University of Technology, PMB 2076, Yola. Adamawa state. Nigeria.
}

\begin{tabular}{l} 
ARTICLE INFO \\
\hline Article history: \\
Received on: $28 / 01 / 2014$ \\
Revised on: $23 / 07 / 2014$ \\
Accepted on: 02/08/2014 \\
Available online: $30 / 10 / 2014$ \\
\hline Key words: \\
Alloxan, diabetes mellitus, \\
Balanite aegyptiaca, kernel \\
cake, supplementation
\end{tabular}

\begin{abstract}
Diabetes mellitus is one of the disease for which a satisfactory treatment is not available in modern allopathic system of medicine. Therefore, there is a need to develop newer treatment strategies of plant origin as they are known to have fewer side effects. The present study investigated the possible therapeutic effects of Balanite aegyptiaca kernel cake on certain biochemical markers in alloxan-induced diabetes mellitus in rats. Diabetes was induced in albino rats by single intraperitoneal injection of Alloxan $(70 \mathrm{mg} / \mathrm{kg}$ body weight). Normal diet supplemented with $10 \%$ and $20 \%$ of kernel cake of Balanites aegyptiaca were fed to diabetic rats for three weeks. The effects of the aegyptiaca kernel cake on blood glucose, albumin, urea, creatinine, total cholesterol, triglyceride and the activities of liver marker enzymes aspartate aminotransferase, alanine aminotransferase, and alkaline phosphatase were examined in the serum of control and treated groups. Supplementation of Balanites aegyptiaca kernel cake $10 \%$ and $20 \%$ to diabetic rats for Three weeks significantly reduced blood glucose $(451.80 \pm 5.4$ to $408.60 \pm 1.8)$, urea $(429.30 \pm 1.10$ to $203.40 \pm 4.1)$, and creatinine $(2.05 \pm 0.05$ to $1.80 \pm 0.21)$ but increased the levels of albumin ( $3.14 \pm 0.07$ to $3.50 \pm 0.01)$, and restored all marker enzymes to near normal levels. The present results showed that Balanites aegyptiaca kernel cake has an antihyperglycaemic and antihyperlipidemic effect and consequently may alleviate liver and renal damage associated with Alloxan induced diabetes mellitus in rats.
\end{abstract}

\section{INTRODUCTION}

Medicinal plants are widely used in management of diseases all over the world (Rahman et al., 2005; Aliyu et al., 2007) historically; the use of medicinal plants is as old as mankind and medicine. Balanites aegyptiaca $(L)$ Del. is a perennial tropical plant used in food preparations and herbal medicine, especially in Africa and some developing countries. It is also called desert date (English), adua (Hausa, Nigeria), tanni (Fulfulde, Nigeria) and heglig (Arabic). B. aegyptiaca belongs to the family Balanitecea. The plant attains a height of more than 6 meters. It has a multiplicity of uses and almost every part of the plant is useful including, leaves, thorns, back of root and fruit. B.aegyptiaca is used to treat so many illnesses including, diarrhoea, hermorrhoid, stomach aches, jaundice, yellow fever, syphilis and epilepsy (Ojo et al., 2006). For instance, the fruit is used to treat liver disease and as a purgative and sucked by schools children as a confectionary in some countries (Barley, 1962 and Croach, 1962). The bark is used in the treatment of syphilis, round worm infection

* Corresponding Author

E-mail: msnadro@yahoo.com.

Tel: $+2348053472090,+2348134231230$ and as fish poison (Gajalakshmi et al., 2013). The aqueous leaf extract and saponins isolated from its kernel cakes have anti bacterial activity (Bashir et al., 1984 and Doughari et al., 2007) and potent larvicidal activity. The fleshy pulp of both unripe and ripe fruit is edible and eaten dried or fresh. The fruit is processed into a drink and sweetmeats in Ghana, alcoholic liquor in Nigeria, a soup ingredient in Sudan. Young leaves and tender shoots are used as a vegetable, which is boiled, pounded, then fried or fat added to prepare it. The flowers are a supplementary food in West Africa and an ingredient of 'dawa dawa' flavoring in Nigeria. Flowers are sucked to obtain nectar (Hines et al., 1993). The kernels produce edible oil used for cooking. The oil remains stable when heated and has a high smoking point, and therefore its free fatty acid content is low. Its scent and taste are acceptable (Hines et al., 1993, Wilson et al., 2009). Currently, the treatment of diabetes mainly involves a sustained reduction in hyperglycemia by the use of biguanides, thiazolidinediones, sulphonylureas, Diphenylalanine derivatives, meglitinides and $\alpha$-glycosidase inhibitors in addition to insulin. However, due to unwanted side effects the efficacies of these compounds are debatable and there is a demand for new compounds for the treatment of diabetes (Thirunavukkarasu et al., 
2003). Hence, plants have been suggested as a rich, as yet unexplored source of potentially useful anti diabetic drugs. However, only a few have been subjected to detailed scientific investigation (Saxena and Vikram, 2004). This study is aimed at assessing the effects of the kernel cake on the system of diabetic rats using biochemical and haematological analysis.

\section{MATERIALS AND METHODS Chemicals}

All the chemicals used in the study are of analytical grade.

\section{Sample Collection}

The Balanite aegyptiaca kernel cake used for the study was collected from Garkida, Gombi local government area of Adamawa state. Nigeria. The cake was pounded using mortar and pestle to fine particles before administration.

\section{Methodology}

Twenty (20) young albino male rats weighing $120 \pm$ $8.43 \mathrm{~g}$ were purchased from the animal house unit of National Veterinary Research Institute (NVRI) Vom, Plateau State. Nigeria. The animals were allowed to adapt to the new environment for one week before the commencement of the experiment. The animals were housed under standard experimental condition and were fed with standard diet of vital feed grinds cereals and oil mills, Jos. Nigeria.

\section{Induction of Diabetes}

Diabetes was experimentally induced in male albino rats by administration of diabetogenic dose of alloxan $(70 \mathrm{mg} / \mathrm{kg}$ body weight dissolved in normal saline) intraperitoneally. The remaining rats were injected normal saline through the same route (Adoga and Bukar, 1994; Pepato et al., 2004). After seven (7) days, only those rats which had blood glucose levels $>250 \mathrm{mg} / \mathrm{dl}$ were classified as diabetic and were included in the study.

\section{Experimental Design}

The rats were divided into four groups comprising five animals in each group as follows:

\begin{tabular}{ccc}
\hline $\begin{array}{c}\text { Groups GroupA } \\
\text { (Normal control) }\end{array}$ & $\begin{array}{c}\text { \% Doses } \\
\mathbf{1 0 0} \text { normal diet }\end{array}$ & $\begin{array}{c}\text { Diet Fed } \\
\text { Normal diet }\end{array}$ \\
\hline GroupB (Diabetic control) & 100 normal diet & Normal diet \\
Group C (Supplement1) & $10+90 \%$ normal diet & Balanite aegyptiaca \\
Group D (Supplement2) & $20+80 \%$ normal diet & Balanite aegyptiaca \\
\hline
\end{tabular}

Treatments continued for 21 days. At the end of the experiment, blood was collected by cardiac puncture under mild anaesthesia from overnight fasted rats and serum was separated and analyzed for biochemical parameters.

\section{RESULTS}

Table 1 shows that there was significant increased at $(p<0.05)$ in the weight of diabetic rats that had their diets supplemented when compared to the diabetic control. Serum glucose levels was found to be elevated in diabetic groups as compared to the normal control and was shown to be significantly reduced at $(\mathrm{p}<0.05)$ at a dose of 10 and $20 \%$ of $B$. aegyptiaca cake. The mean serum albumin of untreated and treated diabetic rats is shown in Table 2. The reduced levels of albumin in alloxaninduced diabetic rats were improved in the treated groups. Table 2 , shows the levels of urea and creatinine of normal and alloxan induced diabetic rats. These biochemical variables were elevated in the diabetic rats, supplementation of 10 and $20 \%$ of $B$. aegyptiaca cake significantly $(\mathrm{p}<0.05)$ lowered the urea and creatinine levels in alloxan - induced diabetic rats. Table 3 shows that there was significant hyperlipidemia due to experimental diabetes mellitus. B. aegyptiaca kernel cake supplement reduced serum cholesterol and triglycerides levels significantly $(\mathrm{p}<0.05)$.

Table 4 gives a summary of the effect of B.aegyptiaca cake supplementation on the activities of serum enzymes AST, ALT and ALP in Alloxan induced diabetes mellitus. The activities of these serum enzymes were found to be significantly increased in diabetic rats. B. aegyptiaca had a lowering effect on the enzymes which was statistically significant when compared with diabetic control rats. Table 5 Shows a decreased in the hematological parameters such as PCV, WBC count, RBC count, Platelet and haemoglobin $(\mathrm{Hb})$ in Alloxan-diabetes compared to the control (Group 1). Supplementation of B. aegyptiaca cake increased the levels of these parameters.

Table 1: Effect of Balanite aegyptiaca kernel cake as supplement on body weight $(\mathrm{g})$ of normal and Alloxan-induced diabetes in rats.

\begin{tabular}{lccl}
\hline \multicolumn{1}{c}{ Treatment } & $\begin{array}{c}\text { Initial } \\
\text { Weight }(\mathbf{g})\end{array}$ & $\begin{array}{c}\text { Final weight } \\
(\mathbf{g})\end{array}$ & \% Weight gain \\
\hline Normal control & $155.13 \pm 1.47$ & $197.70 \pm 1.55$ & $27.44 \pm 5.44$ \\
Diabetic control & $132.97 \pm 5.09$ & $110.03 \pm 0.80$ & $-17.25 \pm-84.29$ \\
$\begin{array}{l}\text { Diabetic }+10 \% \\
\text { supplement }\end{array}$ & $164.73 \pm 1.12$ & $184.11 \pm 1.58$ & $11.76 \pm 41.07$ \\
$\begin{array}{l}\text { Diabetic +20\% } \\
\text { supplement }\end{array}$ & $150.86 \pm 1.41$ & $164.15 \pm 2.48$ & $8.81 \pm 75.87$ \\
Values are expressed in Mean \pm S.E.M for $(\mathrm{n}=5)$ &
\end{tabular}

Table 2: Effects of B. aegyptiaca kernel cake on some biochemical parameters in Alloxan- induced diabetes in rats.

\begin{tabular}{lccc}
\hline \multicolumn{1}{c}{ Treatment } & $\begin{array}{c}\text { Serum glucose } \\
(\mathbf{~ m g / d l})\end{array}$ & $\begin{array}{c}\text { Albumin } \\
(\mathbf{g} / \mathbf{d l})\end{array}$ & Urea ( mg/dl) \\
\hline Normal control & $149.40 \pm 2.60$ & $4.20 \pm 0.01$ & $117.90 \pm 2.70$ \\
$\begin{array}{l}\text { Diabetic control } \\
\text { Diabetic +10\% } \\
\text { supplement }\end{array}$ & $451.80 \pm 5.40$ & $3.14 \pm 0.07$ & $429.30 \pm 1.10$ \\
$\begin{array}{l}\text { Diabetic }+20 \% \\
\text { supplement }\end{array}$ & $322.8 \pm 5.40^{*}$ & $3.50 \pm 0.01$ & $221.40 \pm 1.05^{*}$ \\
\hline
\end{tabular}

Values are expressed in Mean \pm S.E.M for $(n=5)$. ${ }^{*}$ Significantly lower compared to the values obtained for diabetic control $(\mathrm{p}<0.05)$.

Table 3: Effects of B. aegyptiaca kernel cake on lipid profile parameters in normal and Alloxan- induced diabetes mellitus in rats.

\begin{tabular}{lll}
\hline Treatment & Total cholesterol (mg/dl) & Triglyceride (mg/dl) \\
\hline Normal control & $51.25 \pm 3.95$ & $44.85 \pm 5.65$ \\
Diabetic control & $83.75 \pm 2.95$ & $225.00 \pm 1.00$ \\
10\% supplement & $71.45 \pm 4.75^{*}$ & $115.00 \pm 5.00^{*}$ \\
$20 \%$ supplement & $71.45 \pm 4.75^{*}$ & $120.00 \pm 0.10^{*}$ \\
\hline
\end{tabular}

Values are expressed in Mean \pm S.E.M for $(n=5)^{*}$ Significantly lower compared to the values obtained for diabetic control $(\mathrm{p}<0.05)$. 
Table 4: Effect of Balanite aegyptiaca kernel cake as supplement on serum activities of some marker enzymes in rats with allozanized experimental diabetes mellitus.

\begin{tabular}{lccc}
\hline \multicolumn{1}{c}{ Treatment } & AST U/L & ALT U/L & ALP U/L \\
\hline Normal control & $45.00 \pm 4.00$ & $23.50 \pm 0.50$ & $64.35 \pm 0.45$ \\
Diabetic control & $124.00 \pm 1.00$ & $60.00 \pm 2.00$ & $78.70 \pm 0.90$ \\
$10 \%$ supplement & $104.00 \pm 2.00^{*}$ & $45.00 \pm 3.00^{*}$ & $72.15 \pm 2.45^{*}$ \\
$20 \%$ supplement & $96.00 \pm 0.01^{*}$ & $29.00 \pm 2.00^{*}$ & $72.10 \pm 0.50^{*}$ \\
\hline Vas
\end{tabular}

Values are expressed in Mean \pm S.E.M for $(n=5)$

* Significantly lower compared to the values obtained for diabetic control $(\mathrm{p}<0.05)$

Table 5: Effects of B.aegyptiaca kernel cake as supplement on the hematological parameters in normal and Alloxan-induced diabetes mellitus in rats.

\begin{tabular}{|c|c|c|c|c|c|}
\hline Treatment & PCV (\%) & $\mathrm{WBC}\left(\times 10^{3} / \mu \mathrm{l}\right)$ & RBC $\left(\times 10^{6} / \mu \mathrm{l}\right)$ & Platelet $\left(\times 10^{3} / \mu \mathrm{l}\right)$ & Haemoglobin (g/dl) \\
\hline Normal control & $45.20 \pm 2.40$ & $6.300 \pm 0.70$ & $6.88 \pm 0.65$ & $396.00 \pm 4.0$ & $15.07 \pm 0.80$ \\
\hline Diabetic control & $33.85 \pm 0.85$ & $2.85 \pm 1.05$ & $4.89 \pm 0.01$ & $56.50 \pm 1.50$ & $11.29 \pm 0.29$ \\
\hline $10 \%$ supplement & $41.30 \pm 0.9^{*}$ & $5.20 \pm 0.10^{*}$ & $6.13 \pm 0.01 *$ & $212.50 \pm 0.50 *$ & $13.77 \pm 0.30$ \\
\hline $20 \%$ supplement & $42.50 \pm 0.40 \%$ & $4.50 \pm 0.04$ & $4.50 \pm 0.04 *$ & $111.00 \pm 2.00^{*}$ & $12.64 \pm 0.14$ \\
\hline
\end{tabular}

Values are expressed in Mean \pm S.E.M for $(n=5)$

* Significantly different compared to the values obtained for diabetic control $(\mathrm{p}<0.05)$

\section{DISCUSSION}

Diabetes is characterized by weight loss. Alloxan induction brought about marked reduction in body weight of rats. Supplementation of the rats' normal chow with 10 and 20 percent $B$. aegyptiaca cake brought about an increased in the body weight (tables 1)

Alloxan monohydrate is known to induce diabetes by partial destruction of pancreatic beta cells of islet of langerhan (Obaid, et al., 2004). This results in depletion of insulin levels and hyperglycemia leading to type 1 diabetes mellitus. The Alloxantreated rats, therefore, appear to represent a good laboratory model for IDDM, experimental diabetes state, with residual or remnant insulin production by the pancreatic beta -cells. There is possibility for the survival of a few beta-cells and this has been proved by several workers who observed antihyperglycemic activity with oral hypoglycemic agents like glibenclamide, tolbutamide etc. in Alloxan-induced diabetic rats (Sheeja and Augusti, 1993; Kumud and Mathew, 1995; Subramoniam et al.,1996) The diabetic state of Alloxan- treated diabetic rats is therefore, not the same as that obtained by total pancreatectomy, as daily administration of insulin is not required for the survival in Alloxan-treated diabetic animals.

Medicinal plant extracts have been valuable anti-diabetic agents and may involve one or more active components responsible for blood glucose reduction (Grover et al., 2002, Nadro and Onoagbe, 2012). Flavonoids of different plant origin showed a promising anti-diabetic activity, as demonstrated in diabetic animal models (Kim et al., 2004). Saponins are glycosides of triterpenes, steroids or alkaloids. Our results revealed that, Wistar rats treated for three weeks with B. aegyptiaca kernel cake resulted in a significant reduction $(\mathrm{p}<0.05)$ in the blood glucose levels of diabetics, when compared to control group. High levels of triglycerides have been associated with heart disease, insulin resistance and diabetic mellitus (Prince et al., 2004; Punitha and Monoharan, 2006). The abnormally high concentration of serum lipids in diabetics is mainly due to increase in the mobilization of free fatty acids from the peripheral fat depots since insulin inhibits hormone sensitive lipase (Akah et al., 2004).
The reduction in $\mathrm{TC}$ and $\mathrm{TG}$ may be due to low activity of cholesterol biosynthesis enzymes and or low level of lipolysis and are under the control of insulin (Sharma et al., 2003). The reduction in albumin level was observed in diabetic rats and this is consistent with the results obtained by Bakris, (2001) and Tuvemo et al., (2006). The decrease in albumin may be due to albuminuria which are important clinical markers of diabetic nephropathy (Mauer et al., 2007) and/or may be due to increased protein catabolism (Almdal and Vilstrup, 2005). The results of the present study demonstrated that the treatment of diabetic rats with the caused a noticeable elevation in the albumin levels as compared with their normal levels (Safiyeh et al., 2007). A significant elevation in serum creatinine and urea levels indicates an impaired renal function of diabetic animals (Shinde et al., 2003). Thus, it would appear that the B. aegyptiaca kernel cake supplement lowered the serum urea, and creatinine levels by enhancing the renal function that is generally impaired in diabetic rats. In order to determine if the cake used here, had any toxicity in general, we measure the hepatic AST, ALT, ALP activities which are general indicators of toxicity (Ghosh et al., 2001). The levels of AST, ALT and ALP have been reported to be increased in Alloxaninduced diabetic rats (Nwanjo, 2007). In this investigation $B$ aegyptiaca kernel cake significantly $(\mathrm{p}<0.05)$ reduced elevated levels of ALT, AST and ALP thus improving renal and hepatic functions. Literature has shown that ingestion of medicinal compounds or drugs can alter the normal range of hematological parameters (Ajagbonna et al., 1999). In our study PCV levels decrease in diabetic rats is a result of RBC's haemolysis. On the other hands, the levels of these parameters (RBC's and PCV) were significantly increased in diabetic rats treated with $B$. aegyptiaca kernel cake. Thus, increased RBC's count and PCV value in these rats appears to be due to the lowered lipid peroxidation level in RBC's membrane leading to a decrease susceptibility of RBC's to haemolysis. The increased lipid peroxidation in the RBC's is also due to an inhibition or changing the activity of non enzymatic and enzymatic components of the oxidative system (reduced glutathione (GSH), Superoxide Dismutase (SOD) and Catalase (CAT) activities (Udoh et al., 2007). 


\section{CONCLUSION}

In conclusion, these results confirmed the used of $B$. aegyptiaca cake in traditional medicine for the management of diabetes mellitus. The results suggested that up to $20 \%$ of $B$. aegyptiaca cake has a potent hypoglycemic and hypolipidaemic activity which is capable of normalizing other biochemical and hematological abnormalities associated with diabetes mellitus thus, could be prescribed as adjunct to dietary therapy and main therapy for diabetes mellitus.

\section{REFERENCES}

Adoga G.I and Ibrahim M B. Effect of garlic oil on some biochemical parameters in Streptozotocin-induced diabetic rats. Medicinal Science Research, 1990; 18: 859-60.

Ajagbonna, O.P., K.I. Onifade and Suleiman, U. Haematological and biochemical changes in rats given Calotropis procera. Sokoto Journal of Vetenary Science, 1999; 1(1): 36-42

Akah, P.A., O. Njoku, A. Nwanguma and Akunyili, D. Effect of aqueous leaf extract of Vernonia amygdalina on blood glucose and triglyceride levels of alloxan-induced diabetic rats (Rattus rattus). Animal Research International, 2004; 1: 90-94.

Aliyu, R., A.H. Adebayo, D. Gatsing and Garba, I.H. The effects of ethanolic leaf extract of Balanite Aegyptiaca (Balanaeceae) on rat liver and kidney functions. Journal of Pharmacology and Toxicology, 2007; 2: 373-379.

Almdal TP, Vilstrup H. Effect of streptozotocin-induced diabetes and diet on nitrogen loss from organs and the capacity of urea synthesis in rats. Diabetologia, 2005; 30:952-6.

Asgary, S., G.A. Naderi, N. Sarrafzadegan and M. Ghasemi. Antioxidant effect of lavonoids on hemoglobin glycosylation. Pharmacology Acta Helv, 1999; 73: 223-226.

Bakris GL. Diabetic nephropathy. What you need to know to preserve kidney function. Postgraduate Medicine, 2001; 93:89-94.

Barley S. Zygophyllaceae.In:Watt,J.M and Breyer- Brandwijk, M.G, ed. The Medicinal and poisonous plants of Southern and Eastern Africa.Livingstone Ltd.London: 1962; 1064.

Bashir AK, Ahmed GHM, Suliman SM, ElKheir YM. Molluscicidal and other Biological activities of B.aegyptiaca. The first Arab Conference on Medicinal plants, Cairo, Egypt, 1984.

Croach P. Zygophyllaceae.In:Watt,J.M and Breyer- Brandwijk, M.G, ed. The Medicinal and poisonous plants of Southern and Eastern Africa.Livingstone Ltd. London. 1962; pp. 1064.

Doughari JM, Pukuma MS, De N. Antibacterial effects of Balanites aegyptiaca L. Del. and Moringa oleifera Lam. on Salmonella typhi. Africa Journal of Biotechnology, 2007; 6 (19): 2212-2215.

Gajalakshmi S, Vijayalakshmi S, Devi Rajeswari V. Pharmacological Activities of Balanites aegyptiaca(1.)-A Perspective Review. International Journal of Pharmaceutical Science Review Research, 2013; 22(1), nº 23, 117-120

Hines DA, Eckman K. Indigenous multipurpose trees for Tanzania: uses and economic benefits to the people. Cultural survival Canada and Development Services Foundation of Tanzania.

Kim HY, Moon BH, Lee HJ, Choi, DH. Flavonoids glycosides from the leaves of Eucommia ulmoides with gycation inhibitory activity. Journal of Ethnopharmacology, 2004; 93: 227-230.

Kumud K, Mathew BC Antidiabetic and hypolipidemic effects of S-methyl cysteine sulfoxide isolated from Allium cepa Linn, Indian Journal of Biochemistry and Biophysics, 1995; 32: 49-54.

Mauer SM, Steffes MW, Brown DM. The kidney in diabetes. American Journal of Medicine, 2007; 70: 63-6.

Nadro, M. S. and Onoagbe, I. O. Anti-hyperlipidaemic and antioxidant effect of aqueous and ethanolic extracts of Cassia italica leaves in streptozotocin-induced diabetes in rats. Journal of Medicinal Plants Research, 2012; 6(31), pp. 4675-4681
Nwanjo, H.U. Studies on the effect of aqueous extract of Phyllanthus niruri on plasma glucose level and some hepatospecific markers in diabetic Wistar rats. International Journal of Laboratory Medicine, 2007; 2(2): 1-18.

Obaid M, Turtle JR. Type 2 diabetes: an epidemic in the making. ADF. 2004; 5: 29-34.

Ojo OO, Nadro MS, Tella IO, Protection of rats by extracts of some common Nigerian trees against acetaminopheninducedhepatotoxicity. Africa Journal of Biotechnology, 2006; (9):755760.

Prince, S.M, Kamalakkanan N, Venugopal P.M, Antidiabetic and antihyperlipidemic effect of alcoholic Syzigium cumini kernels in Alloxan-induced diabetic albino rats. Journal of Ethnopharmacology, 2005; 91:209-213.

Punitha, R. and Manoharan, S. Antihyperglycemic and antilipidperoxidative effects of ongamia pinnata (Linn) Pierre flowers in Alloxan induced diabetic rats. Journal of ethnopharmacology, 2006; 105: 39-46.

Rahman, M.W., M. Mostofa, S.A. Sardar, M.R. Sultana, M.M. Haque and M.E. Choudhury. Investigation of comparative hypoglycemic effect of neem (Azadirachta indica), karala (Momordica charantea) and nayantara (Cathranthus roseus) with glibenclamide on rat. International Journal of Pharmacology, 2005;1:257-260.

Saxena, A. and Vikram, N. K. Role of selected Indian plants in management of type 2 diabetes. A review. Journal of Alternative and Complementary Medicine, 2004; 10:369-378.

Sharma, S.B., Nasir, A., Prabhu, K.M., Murthy, P.S., Dev, G. Hypoglycaemic and hypolipidemic effect of ethanolic extract of kernels Eugenia jambolana in alloxan-induced diabetic rats. Journal of Ethnopharmacology, 2003; 85: 201-206.

Sheeja C, Augusti KT. Antidiabetic effect of a glycoside of Leucopelargonidin isolated from Ficus bengalensis Linn. Indian Journal of Experimental Biology, 1993; 31: 26-29

Shinde UA, Goyal RK. Effect of chromium picolinate on histopathological alterations in Alloxan and neonatal alloxan diabetic rats. Journal of Cell Molecular Medicine, 2003; 7:322 -9.

Subramoniam A, Pushpagandan P, Rajasekharan S, Evans DA, Latha PG, Valsaraj R.Effect of Artemisia pallens Wall on blood glucose levels in normal and alloxan induced diabetic rats. Journal of Ethnoparmacology, 1996; 50: 13-17.

Thirunavukkarasu, V., C.V. Anuradha and P. Viswanathan. Protective effect of fenugreek (Trigonella foenum graecum) kernels in experimental ethanol toxicity. Phytotherapy Research, 2003; 17:737-743.

Tuvemo T, Ewald U, Kobboh M, Proos LA, Serum magnesium and protein concentrations during the first five years of insulin dependent diabetes in children. Acta Paediatrician Supplement, 2006; 418:7-10.

Udoh, A.E., N. Iya, E. Okon andMary, N. Red cell catalase activity in diabetics. Pakistan Journal of Nutrition, 2007; 6:511-515.

Wilson, O., Nadro, M. S., Tiyafo, G.O. and Wurochekke A.U. Toxicity of Balanites egyptiaca kernel oil in rats. Journal of America Science, 2009; 5 (6): 13-16.

How to cite this article:

Nadro MS and Samson FP. The effects of Balanite aegyptiaca kernel cake as supplement on alloxan-induced diabetes mellitus in rats. J App Pharm Sci, 2014; 4 (10): 058-061. 